\title{
$\mathrm{BCG}$ 림프절염의 외과적 치료

\author{
이 남 혁
}

영남대학교 의과대학 외과학교실

\section{Surgical Treatment of BCG Lymphadenitis}

\author{
Nam Hyuk Lee \\ Department of Surgery \\ College of Medicine, Yeungnam University, Daegu, Korea
}

\section{- Abstract-}

Background : Regional lymphadenitis is a common complication after BCG vaccination and has various clinical course. Various treatment, including medical, surgical, and combined are used to treat BCG lymphadenitis, but results are controversial. This study was performed to provide guidelines for surgical approach to BCG lymphadenitis.

Materials and Methods : 37 patients with BCG lymphadenitis at Yeungnam University Hospital between March 2004 and August 2007 were retrospectively reviewed. Suppurative BCG lymphadenitis were treated by surgical excision or incision and curettage. Non-suppurative BCG lymphadenitis were observed without any treatment and surgical treatment was applied when it became suppurative.

Results : The mean age was 7.5 months(range 2-47 months) and most prevalent site of lesion was the ipsilateral axilla. Among 37 cases, 20 cases were already suppurative when diagnosed and 2 cases of 17 non-suppurative BCG lymphadenitis showed spontaneous resolution without any treatment. Surgery was performed successfully on 35 suppurative BCG lymphadenitis and postoperative complication was trivial.

Conclusion : Suppurative BCG lymphadenitis were successfully treated with excision or incision and curettage without any serious complication. So non-suppurative BCG lymphadenitis can be observed expecting spontaneous resolution.

책임저자 : 이남혁, 대구광역시 남구 대명동 317-1, 영남대학교 의과대학 외과학교실

Tel: (053) 620-3584, Fax: (053) 624-1213, E-mail: nhlee@med.yu.ac.kr 
Key Words: BCG, Lymphadenitis, Treatment

\section{서 론}

$\mathrm{BCG}$ 를 접종한 후 그 인근 부위에 발생하는 림프절염은 $\mathrm{BCG}$ 예방접종의 가장 흔한 합병 증으로 접종한 백신의 병독성, 활성도 및 용양, 피접종자의 나이와 면역상태, 그리고 백신의 투여방법과 기술 등에 따라 발생 빈도의 차이 가 있다. ${ }^{1)} \mathrm{BCG}$ 림프절염은 그낭 두면 작은 것 은 일부 자연 소실되기도 하지만 대부분 농양 으로 진행되고 터져서 만성동을 형성하게 되는 것으로 알려져 있다. ${ }^{2-4)} \mathrm{BCG}$ 림프절염의 치료 는 항결핵제를 투여하는 내과적 치료, 흡인 배 농술, 병변내 항결핵제 투여, 외과적 절제술 등 여러 방법이 시행되고 있으며 최선의 방법에 대해서는 아직 논란이 많으나 화농성 림프절염 에 대해서는 외과적 절제술이 가장 많이 시행 되고 있다. ${ }^{3,4)}$ 이에 저자들은 외과적 치료를 받 은 $\mathrm{BCG}$ 림프절염의 임상양상을 분석하여 효 과적인 외과적 치료방법과 시기를 알아보고자 한다.

\section{대상 및 방법}

2004년 3월부터 2007년 9월까지 만 3년 6개 월간 $\mathrm{BCG}$ 림프절염으로 영남대학교 병원 외 과에서 $\mathrm{BCG}$ 림프절염으로 수술 및 경과관찰을 시행한 37 명의 환자들을 관찰 대상으로 $\mathrm{BCG}$ 림프절염의 성별 및 연령별 분포, 발생부위, 치 료결과를 후향적으로 분석하였다. $\mathrm{BCG}$ 접종 후 인접부위에서 발생한 림프절종대로 림프절 염을 유발할 다른 원인이 없을 때 $\mathrm{BCG}$ 림프 절염으로 진단하였고 피부에 홍반을 동반하면 서 눌러보아 말랑말랑하면 화농성 림프절염으 로 진단하였다. 치료는 37 명의 환자 중 첫 진 단 시 화농성 림프절염이었던 20예는 바로 절 제술 혹은 절개배농소파술을 시행하였고 17예 의 비화농성 림프절염환자는 특별한 치료 없이 경과관찰 하다가 화농성 림프절염으로 진행되 면 수술을 시행하였다.

\section{결 과}

전체 37 명의 환자 중 남아 23명(62.2\%), 여아 14 명(37.8\%)으로 남녀 성비는 $1.64: 1$ 이었다. 진단 시 평균 연령은 7.5 개월이었으며 연령 분 포는 2개월부터 47개월까지로 4-6개월이 22예

Table 1. Age and sex distribution

\begin{tabular}{|c|c|c|c|}
\hline \multirow{2}{*}{ Age } & \multicolumn{2}{|c|}{ Number of patients } & \multirow{2}{*}{ Total } \\
\hline & Male & Female & \\
\hline $1-3$ months & 3 & 1 & $4(10.8 \%)$ \\
\hline 4- 6 months & 15 & 7 & $22(59.5 \%)$ \\
\hline 7- 9 months & 2 & 3 & $5(13.5 \%)$ \\
\hline 10-12 months & 1 & 2 & $3(8.1 \%)$ \\
\hline 13- months & 2 & 1 & $3(8.1 \%)$ \\
\hline
\end{tabular}


Table 2. Site of lymphadenitis

\begin{tabular}{lc}
\hline \multicolumn{1}{c}{ Site } & Number of patients \\
\hline Supraclavicular & $4(10.8 \%)$ \\
Axilla & $29(78.4 \%)$ \\
Supraclavicular + axilla & $3(8.1 \%)$ \\
Scapular & $1(2.7 \%)$ \\
\hline
\end{tabular}

(59.5\%)로 가장 많았고 그 다음이 7-9개월로 5 예(13.5\%)였다.(Table. 1) 림프절염의 발생부위 는 37예 중 액와부에 29예(78.4\%), 쇄골상부에 4 예(10.8\%), 액와부와 쇄골상부 양측에 3예(8.1\%), 그리고 견갑부에 1 예(2.7\%)이었다.(Table. 2)

진단 시 림프절염의 상태별로 보면 이미 화 농되어 바로 수술을 시행한 예가 20예(54.1\%) 이고 비화농성 림프절염으로 경과관찰을 시행 한 예가 17예(45.9\%)였으며 이 중 2예(11.8\%) 가 자연치유 되었고 15 예가 화농성 림프절염으 로 진전되어 수술을 시행하였고 화농화 될 때 까지의 기간은 3 주에서 4 개월까지였다.

수술은 16예(45.7\%)에서 절제술을 19예(54.3 $\%)$ 에서 절개배농소파술을 시행하였고 술 후 합병증은 절제술을 시행한 16예 중 2예(12.5\%) 에서 절개 소파술을 시행한 19예 중 2예(10.5 $\%)$ 에서 삼출액의 저류가 있었으나 모두 1-3회 의 바늘흡인으로 해결되었다. 절개 소파술을 시행하였던 19예 중 1 예에서 술 후 1 주에 $1 \mathrm{~cm}$ 크기의 종괴가 다시 촉지되어 $\mathrm{INH}$ 를 투여하며 3 개월간 관찰하였으나 소실되지 않아 절제술을 시행하였으며 그 이유는 재발보다는 다발성 림

Table 3. Complications

\begin{tabular}{ccc}
\hline Complication & Excision(n=16) & $\begin{array}{c}\text { Incision and } \\
\text { curettage }(\mathrm{n}=19)\end{array}$ \\
\hline Seroma & 2 & 2 \\
Recurrence & 0 & 1 \\
\hline
\end{tabular}

프절염을 간과한 결과로 보고 있다.(Table. 3)

\section{고 찰}

결핵을 예방하기 위해 1921년부터 사용되기 시작한 $\mathrm{BCG}$ 백신은 현제 사용되고 있는 백신 중 가장 오래되고 세계적으로 널리 시행되고 있는 백신이나 접종의 효과나 부작용에 대한 논란과 결핵유병율의 차이로 국가별로 시행여 부와 시행시기가 다르다. 그러나 $\mathrm{BCG}$ 접종은 적기에 정량을 올바르게 접종할 경우 비교적 안전한 예방접종으로 알려져 있고 효과적인 면 에서 5-6세 미만의 소아 결핵 특히 결핵성 뇌 막염 및 속립성 결핵과 같은 중증 결핵의 예방 효과가 인정되고 있으면) 우리나라는 결핵의 유병률이 높은 지역이어서 대한 소아 청소년과 학회에서는 모든 신생아에서 생 후 4 주 이내에 접종할 것을 권장하고 있다. ${ }^{6)}$

$\mathrm{BCG}$ 접종의 부작용은 접종부위의 발열, 동 통, 피하농양, 피부궤양 등 다른 예방접종에서 도 발생할 수 있는 경미한 국소 부작용을 비롯 하여 국소 림프절염, 종격동 림프절염, 골수염, 전신감염 등이 보고되고 있다. 이중 국소 림프 절염이 가장 흔한 합병증으로 빈도는 보고자에 따라 $0.03-16 \%$ 로 다양하게 보고되고 있다. ${ }^{4}$, $)$

$\mathrm{BCG}$ 접종 시 접종부위에 생긴 작은 구진은 홍반성 종창, 농포, 궤양으로 진행되어 진액이 분비되는 가피를 형성한 후 약 10-12주가 지 나면 작은 반흔을 남기며 치유된다. ${ }^{8)}$ 그리고 피내에 주사된 $\mathrm{BCG}$ 균은 접종부위에서 빠르 게 증식한 이후 림프배액을 따라 인접 림프절 로 그리고 혈행을 따라 전신의 여러 기관으로 전파되어 각 기관에 결핵균의 폐 감염 초기에 나타나는 것과 유사한 아주 작은 염증성병변을 
형성하게 되는데, 9) 이를 BCGitis라 하며 이는 $\mathrm{BCG}$ 접종이후 면역을 얻는 과정에서 일어나 는 정상적인 반응으로 보고 있다. ${ }^{8)}$

따라서 접종부위의 경미한 이상 반응이나 국소 림프절이 조금 커지는 것은 흔히 볼 수 있는 현상으로 증상이 심하지 않으면 합병증보 다는 접종이후 일어나는 정상적인 반응으로 받 아들이고 있으며, 9) 이러한 림프절 증대와 병 적인 림프절염을 발생 시기나 크기로 구별하는 진단기준이 아직 명확하지 않아,10,11) 일반적 으로 $\mathrm{BCG}$ 림프절염이라 할 때는 림프절의 크 기가 육안적으로 쉽게 관찰되고 만져져 부모의 근심을 유발하는 정도로 큰 경우를 말한다. ${ }^{8,9)}$

$\mathrm{BCG}$ 림프절염의 빈도는 백신의 종류나 형 태, 강도 및 용양, 접종방법과 기술, 피접종자 의 나이와 면역상태 등에 따라 차이가 있다.1,4) 발생 시기는 접종 후 2 주 이내에 발생하거나 1-2년 후에 발생하는 경우도 있으나 대부분 6 개월 이내에 발생하며 본 연구에서도 6 개월 이 내의 환자들의 $70.1 \%$ 를 차지하였다. $\mathrm{BCG}$ 림프 절염의 발생 부위는 상지에 접종 후 흥골 주위 림프절에 대퇴부에 접종 후 복강 내 림프절에 발생하였다는 보고도 있으나 ${ }^{12)}$ 대부분 접종부 위에서 림프가 배액되는 인접 림프절에 발생하 고 가장 흔한 접종 부위가 좌측 견갑부 외측의 삼각근 부위여서 좌측 액와부나 경부에 많이 발생한다. 결핵성 림프절염은 다발성이나 양측 성이 많으나 BCG 림프절염은 대부분 단발성 이고 병변도 하나의 림프절에 국한되어 발생한 다. Ungthavorn는 ${ }^{13)}$ 액와부에 $69.6 \%$ 로 가장 많았고 다음이 쇄골상부와 경부에 각각 $18.5 \%$ 와 $11.9 \%$ 라 했으며 저자의 경우에도 전예가 좌측 삼각근부위에 접종을 받았으며 발생 장소 는 액와부가 29례(78.4\%)로 가장 많았고 쇄골
상부에 4례(10.8\%), 견갑부에 발생한 경우가 1 예(2.7\%)로 거의 대부분이 단발성이었으며 3 례(8.1\%)가 액와부와 쇄골상부 양측에 발생하 였다.

BCG 림프절염은 대부분 표재성으로 돌출되 어 있어 외관상 관찰이나 촉지가 가능하고 발 열이나 압통과 같은 국소증상과 전신증상이 없 는 것이 특징이다. ${ }^{14)}$ 확진을 위해서는 항산균 염색이나 결핵균의 배양과 같은 세균학적 검사 가 필요하나 대부분의 $\mathrm{BCG}$ 림프절염은 병력 상 동측에 $\mathrm{BCG}$ 를 접종하였고 림프절염을 유 발할 특별한 원인이 없으며 이학적 검사상의 특징적인 소견만으로 충분히 진단된다. ${ }^{15)}$

초기의 비화농성 혹은 단순 $\mathrm{BCG}$ 림프절염 단계에는 림프절이 유동적이고 비교적 단단하 고 탄력적으로 만져지며 크기가 작은 것은 종 종 수주에 걸쳐 자연 치유되기도 한다. ${ }^{10,13,14}$ 그러나 일부는 염증이 진행되고 건락괴사가 일 어나 농양을 형성한 화농성 림프절염으로 진전 되어 림프절이 주위조직과 유착되어 고정되고 낭종처럼 말랑말랑하게 만져지며 피부에 염증 이 파급되면 홍반증을 보이게 되고, ${ }^{46)}$ 적절한 치료가 이루어지지 않으면 농양이 터져 농루를 형성하게 된다. 자연 배농으로 형성된 농루도 결국은 자연치유가 되지만 치유되는데 수개월 이 소요되며 그동안 이차감염 방지를 위한 세 심한 창상관리가 필요하며 큰 상흔을 남기게 되므로 그 전에 적절한 치료가 이루어져야 한 다. ${ }^{16)} \mathrm{BCG}$ 림프절염의 $30-80 \%$ 정도가 화농성 림프절염으로 진행된다고 알려져 있으며,11) 진단 시 림프절염의 상태는 Praveen 등 ${ }^{17)}$ 은 단 순 림프절염 보다는 화농성 림프절염이 더 많 았다고 했으나 Ungthavorn 등 ${ }^{15)}$ 은 단순 림프 절염이 더 높은 빈도를 보였다고 했으며 본 연 
구에서는 단순 림프절염이 34예(54\%), 화농성 림프절염이 29예(46\%)였고 농루를 형성한 예 는 없었으며 경과관찰을 시행한 19예의 비화농 성 림프절염 중 17예(89.5\%)가 화농성 림프절 염으로 진행하였다. 림프절염이 농양으로 진전 되는 경향은 신생아기에 접종하거나 ${ }^{9)}$ 림프절 의 크기가 빠른 속도로 커지는 경우 ${ }^{4,15)}$ 농양 으로 진전되는 위험성이 높다고 하며 이미 다 른 원인에 의한 림프절염이 발생해 있을 경우 $\mathrm{BCG}$ 감염이 발생하면 화농으로 진행이 더 빠 르다고 했으나 ${ }^{12)}$ 화농균에 의한 2 차 감염의 역 할은 분명하지 않은 것으로 알려져 있다., ${ }^{8)}$ 진 단 시 림프절의 크기와 화농 위험성의 관계는 명확하지 않으나 Caglayan 등 ${ }^{4)}$ 은 $1.5 \mathrm{~cm}$ 이상 일 때 Ungthavorn과 $\mathrm{Su}-\mathrm{amphan}$ 은 ${ }^{13)} 1.0 \mathrm{~cm}$ 이상의 림프절염은 만성 화농성 염증을 일으켜 대부분 농양으로 진행된다고 했다.

$\mathrm{BCG}$ 림프절염의 치료방법으로는 내과적 치 료, 외과적 치료, 배농술 혹은 침흡인술 등 여 러 방법이 시도되고 있으나 아직은 최선의 방 법에 대한 결론이 없는 상태이다. $\mathrm{BCG}$ 접종이 독성이 없는 균주를 사용하기 때문에 백신이 림프절에 침투되더라도 일부에서 무증상의 단 순 림피절염이 발생된 후 자연소실 될 수 있는 반면 화농성 림프절염을 그냥 두면 자연배농으 로 인한 농루를 형성하게 되어 장기간의 치료 를 요하고 큰 상흔을 남기게 되므로 이를 방지 하는 것이 중요하다. 내과적 치료는 isoniazid과 rifampin 같은 항결핵제를 투여하는 방법과 ${ }^{4)}$ erythromycin을 투여하는 방법 ${ }^{18)}$ 이 시행되고 있으나 비화농성 림프절염이 화농되는 것을 방 지하거나 전체 병기를 줄이는 효과가 미미한 것으로 보고되고 있다. ${ }^{19)}$ 화농성 $\mathrm{BCG}$ 림프절 염이 자연 배농되는 것을 예방하기 위해 침흡
인법을 시행하고 있으며 Banani와 Alborzi는 ${ }^{20)}$ 농양은 자연배농이나 천자 후엔 치유가 촉진되 므로 반복적인 침흡인만으로 치료가 가능하며 특히 침흡인법은 림프절염의 조기치유를 촉진 시키고 자연배농을 방지할 뿐 아니라 농루의 발생 기회를 줄여 준다고 했다. 그러나 건락괴 사에 의한 농은 끈끈하기 때문에 침으로는 충 분한 배농이 어려워 반복적인 흡인이 요구되며 치유기간이 오래 걸리는 문제점이 있으며 다발 성이거나 함께 뭉쳐진 경우 및 반복적인 천자 에도 재발하는 경우에는 외과적 치료가 필요하 다. ${ }^{20)}$

외과적 치료는 한 번의 치료로 완치의 효과 를 얻을 수 있어 병기를 줄일 수 있고 미용적 인 면에서도 만족스러운 결과를 얻을 수 있지 만 전신 마취의 위험성이 있다. 외과적 치료의 시행 시기나 방법은 병소가 농양으로 진전되기 이전에 조기절제술을 시행하는 방법과 농양으 로 진전된 후에 절제술이나 절개배농소파술을 시행하는 방법이 있다. 그러나 본 연구에서도 2 예가 있었듯이 일부의 $\mathrm{BCG}$ 림프절염은 자연 치유의 가능성이 있으므로 모든 $\mathrm{BCG}$ 림프절 염을 조기 절제하는 것은 어린 영유아들을 불 필요한 마취나 수술의 위험성에 노출시키는 과 도한 치료라고 볼 수 있다. 두경부에 발생하는 여러 선천성 낭종은 감염이 되면 항생제나 절 개배농술로 염증을 치료한 다음 절제하는 것이 치료의 원칙이다. 그러나 $\mathrm{BCG}$ 림프절염의 경 우 표재성으로 종괴의 확인이 용이하고 반드시 동반 절제해야 하는 조직경로가 없어 염증이 있어도 절제가 비교적 용이하며 경계가 불분명 하여 주위조직의 손상이 우려되면 농양을 절개 하여 배농한 다음 내부의 모든 건락괴사 조직 을 소파하여 큰 합병증이나 재발없이 쉽게 치 
료할 수 있었다. 술 후 합병증은 절제술을 시 행하였던 예와 절개배농소파술을 시행하였던 예에서 각각 2예씩 4예에서 장액성 삼출액의 저류가 있었으나 1-3회의 주사기 흡인으로 해 결되었으며 절개배농소파술을 시행하였던 19예 중 1 예에서 재발이 있었으나 이 경우 수술 1 주 일 후 외래 방문 시부터 종괴가 촉지된 점으로 보아 재발보다는 다발성 림프절염을 간과하고 불완전 절제하였던 결과로 보고 있다.

\section{요 약}

2004년 3월부터 2007년 8월까지 영남대학교 병원 외과에서 $\mathrm{BCG}$ 접종 후 발생한 림프절염 에 대해 외과적 치료를 시행한 37예를 대상으 로 후향적 임상고찰을 통하여 다음과 같은 결 과를 얻었다.

환자의 평균연령은 7.5 개월이었고 성별 비는 $1.64: 1$ 로 남아에서 많았으며 좌측 액와부와 쇄 골상부에 많이 발생하였다. 외과를 방문 시 $54.1 \%$ 가 이미 화농된 상태였으며 비화농성 림 프절염의 $11.8 \%$ 가 경과관찰 중 자연치유 되었 다.

수술을 시행한 35예의 화농성 림프절염 중 4 예에서 장액성 삼출액의 저류가 있었으나 주 사기 흡인으로 해결되었고 다발성 림프절염을 간과하고 불완전 절제하였던 1 예에서 재수술이 필요하였다.

이상의 결과에서 화농성 $\mathrm{BCG}$ 림프절염은 절제술이나 절개배농소파술로 큰 합병증 없이 치료가 되었으며 비화농성 $\mathrm{BCG}$ 림프절염은 자연치유를 기대하며 경과관찰을 하다가 만약 화농되면 수술을 시행하는 것이 좋을 것으로 사료된다.

\section{참 고 문 헌}

1. WHO tuberculosis research office. Suppurative lymphadenitis following intradermal BCG vaccination of preschool children. Bull World Health Organ 1955;12(1-2):143-67.

2. Muth RG. Suppurative lymphadenitis with caseous tubercle formation after BCG vaccination. N Engl J Med 1958 Jul 17;259(3):131-3.

3. Teo SS, Smeulders N, Shingadia DV. BCG vaccine-associated suppurative lymphadenitis. Vaccine 2005 Apr 8;23(20):2676-9.

4. Caglayan S, Yegin O, Kayran K, Timocin N, Kasirqa E, Gun M. Is medical therapy effective for regional lymphadenitis following BCG vaccination? Am J Dis Child 1987 Nov 141 (11):1213-4.

5. Fine PE. Variation in protection by BCG: implications of and for heterologous immunity [review]. Lancet 1995;346:1339-45.

6. Kim KH, Lee SJ, Lee K. PPD conversion rate and complications according to the different time of BCG vaccination. JKPA 1987;30:487-90.

7. Hengster P, Schnapka J, Fille M, Menardi G. Occurrence of suppurative lymphadenitis after a change of BCG vaccine. Arch Dis Child 1992 Jul;67(7):952-5.

8. Usvedt HJ. Local reactions in BCG vaccination. Bull World Health Organ 1950;2:441-68.

9. Hsing CT. Local complications of BCG vaccination in preschool children and newborn babies. Bull World Health Organ 1954;11:1023-9.

10. Chaves-Carbello E, Sanchez GA. Regional lymphadenitis following BCG vaccination (BCGitis). Clinical comments based upon 25 instances among 1295 childhood vaccinees. Clin Pediatr (Phila) 1972 Dec;11(12):693-7.

11. Oğuz F, Müjgan S, Alper G, Alev F, Neyzi O. Treatment of Bacillus Calmette-Guérin- 
associated lymphadenitis. Pediatr Infect Dis J 1992 Oct;11(10):887-8.

12. Ustvedt HJ. Usual and unusual reactions to BCG inoculation in children. .Am Rev Tuberc 1956 Aug;74(2):32-42.

13. Ungthavorn $\mathrm{P}, \mathrm{Su}^{-}$amphan $\mathrm{A}$. Management of lymphadenitis following BCG vaccination. J Med Assoc Thai 1978 May;61(5):256-9.

14. Victoria MS, Shah BR. Bacillus CalmetteGuérin lymphadenitis: a case report and review of the literature. Pediatr Infect Dis 1985 MayJun;4(3):295-6.

15. Helmick CG, D'Souza AJ, Goddard N. An outbreak of severe BCG axillary lymphadenitis in Saint Lucia, 1982-83.West Indian Med J 1986 Mar;35(1):12-7.

16. Carayan S, Arikan A, Yaprak I, Aksoz K, Kansoy S. Management of suppuration in regional lymph nodes secondary to BCG vaccination. Acta Paediatr Jpn 1991 Dec;33(6): 699-702.

17. Praveen KN, Smikle MF, Prabhakar P, Pande D, Johnson B, Ashley D. Outbreak of Bacillus Calmette-Guérin-associated lymphadenitis and abscesses in Jamaican children. Pediatr Infect Dis J 1990 Dec;9(12):890-3.

18. Power JT, Stewart IC, Ross ID. Erythromycin in the management of troublesome BCG lesions. Br J Dis Chest 1984 Apr;78(2):192-4.

19. Goraya JS, Virdi VS. Treatment of CalmetteGuérin bacillus adenitis: a metaanalysis. Pediatr Infect Dis J 2001 Jun;20(6):632-4.

20. Banani SA, Alborzi A. Needle aspiration for suppurative post-BCG adenitis. Arch Dis Child 1994 Nov;71(5):446-7. 